\title{
Intraparenchymal pericatheter cyst in ventriculoperitoneal shunt failure
}

\author{
David J Wallace, Ramesh Grandhi
}

Neurosurgery, UT Health San Antonio, San Antonio, Texas, USA

Correspondence to Dr Ramesh Grandhi,

rameshmgrandhi@gmail.com

\section{Accepted 12 May 2017}

CrossMark

\section{To cite: Wallace $D$} Grandhi R. BMJ Case Rep Published Online First: [please include Day Month Year]. doi:10.1136/bcr-2017 220468

\section{DESCRIPTION}

A 60-year-old man status post right parieto-occipital ventriculoperitoneal shunt with programmable valve for indication of delayed hydrocephalus after aneurysmal subarachnoid haemorrhage returns to

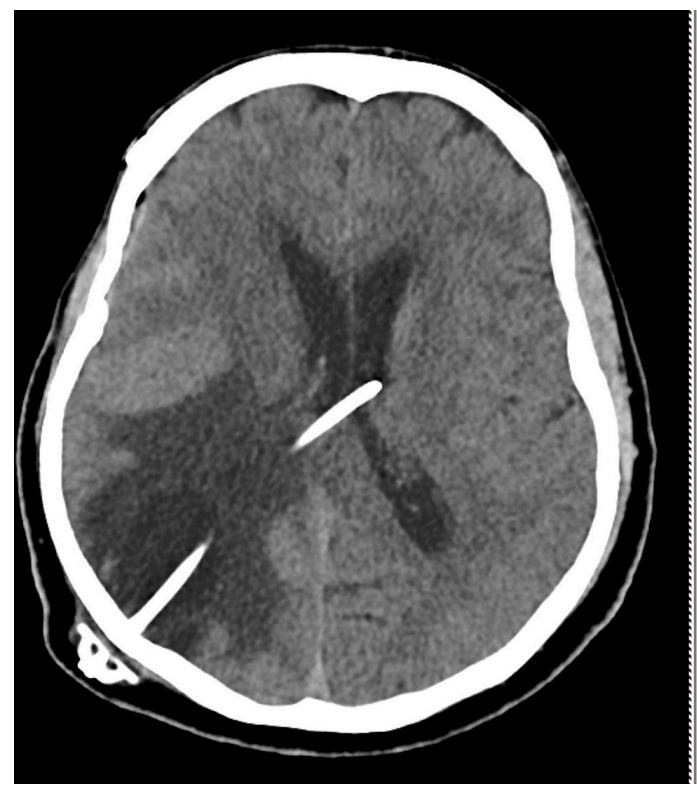

Figure 1 Head CT without contrast at the time of the failure and cyst.

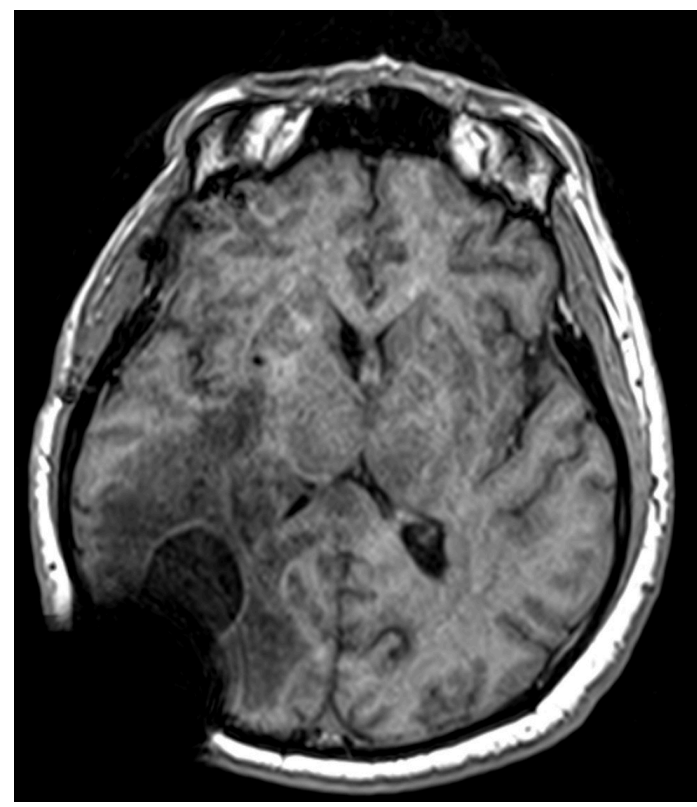

Figure 2 Brain MRI without contrast demonstrating the cyst (with artefact from the shunt near the skull).

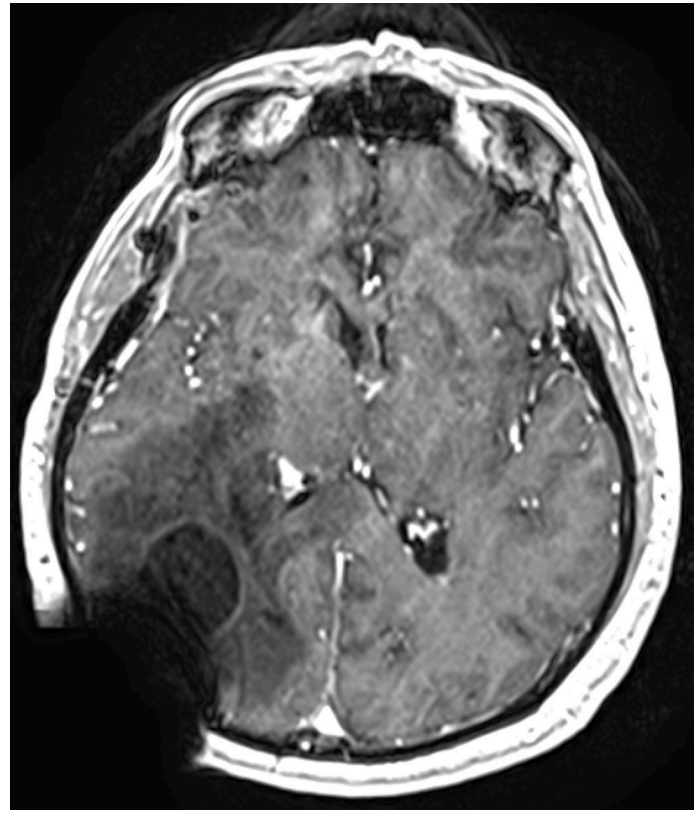

Figure 3 Brain MRI with contrast demonstrating the non-enhancing pattern of the cyst (with artefact from the shunt near the skull).

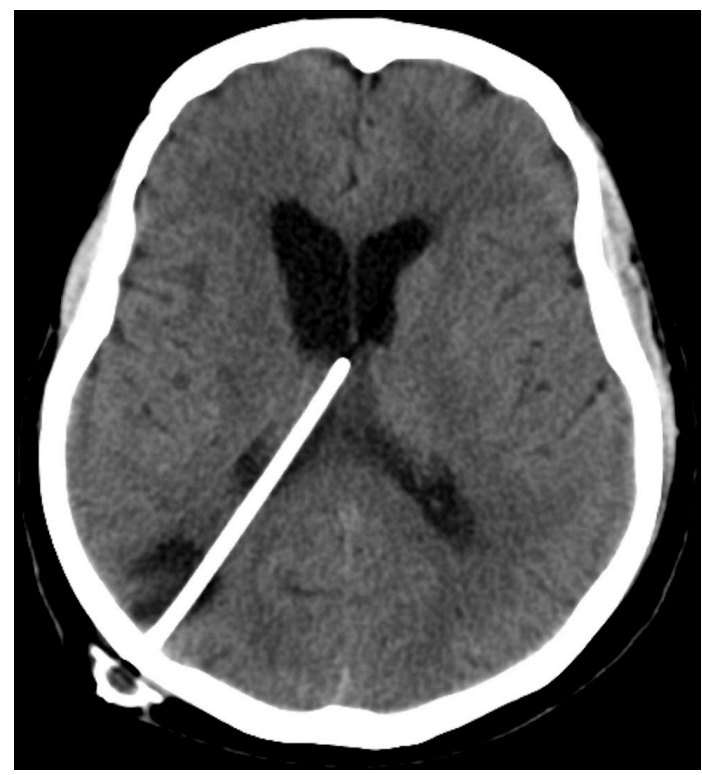

Figure 4 Head CT without contrast at follow-up visit showing resolution of the cyst and oedema.

clinic 7 weeks after placement for insidious onset of headaches, confusion and gait imbalance. CT scan of the head without contrast revealed an intraparenchymal pericatheter cystic collection with severe 
oedema (figure 1). The patient denied systemic signs of illness, and laboratory markers for infection were low. A tap of the shunt reservoir revealed no spontaneous flow and difficulty in aspirating cerebrospinal fluid (CSF). Laboratory analysis of the fluid showed negative Gram stain, normal chemistry profile and cell counts. MRI of the brain showed a simple cyst with significant oedema, but no restricted diffusion or contrast enhancement of the cyst wall (figures 2 and 3). CT of the abdomen was benign, without evidence of pseudocyst or other cause of distal obstruction.

The patient was taken to the operating theatre for exploration of the shunt system with high suspicion for proximal mechanical failure. The proximal catheter was disconnected, and found to have no spontaneous flow of CSF. A new proximal catheter was placed using neuronavigation, and spontaneous flow was observed. The system was interrogated, reconnected and incision closed.

The patient had immediate improvement in symptoms. All cultures were negative. He was discharged home on postoperative day 1 . With negative cultures, diagnosis of brain abscess was excluded, and intraparenchymal pericatheter cyst was confirmed, a rare, but known, complication of proximal ventriculoperitoneal shunt failure. ${ }^{1}$ Follow-up CT scan 6 weeks later demonstrated near-complete resolution of the pericatheter cyst, with improvement in oedema (figure 4).

\section{Learning points}

- Intraparenchymal pericatheter cyst is a rare complication of shunt failure.

- Complete resolution can occur with shunt revision only.

- Identification can avoid shunt explantation, craniotomy and multiple surgeries as would be required if treated as a brain abscess.

Contributors DJW contributed in acquisition and editing of the images, and drafting the manuscript. RG contributed in final revision of the manuscript. Both authors contributed in conception and critical revision of the manuscript.

Competing interests None declared.

Patient consent Obtained.

Provenance and peer review Not commissioned; externally peer reviewed.

(c) BMJ Publishing Group Ltd (unless otherwise stated in the text of the article) 2017. All rights reserved. No commercial use is permitted unless otherwise expressly granted.

\section{REFERENCE}

1 Iqbal J, Hassounah M, Sheikh B. Intraparenchymal pericatheter cyst. A rare complication of ventriculoperitoneal shunt for hydrocephalus. Br J Neurosurg 2000;14:255-8.

Copyright 2017 BMJ Publishing Group. All rights reserved. For permission to reuse any of this content visit

http://group.bmj.com/group/rights-licensing/permissions.

BMJ Case Report Fellows may re-use this article for personal use and teaching without any further permission.

Become a Fellow of BMJ Case Reports today and you can:

- Submit as many cases as you like

- Enjoy fast sympathetic peer review and rapid publication of accepted articles

- Access all the published articles

- Re-use any of the published material for personal use and teaching without further permission

For information on Institutional Fellowships contact consortiasales@bmjgroup.com

Visit casereports.bmj.com for more articles like this and to become a Fellow 